International Journal of Biological Research, $2(2)(2014) 44-47$
International Journal of Biological Research
Journal home page: $\begin{gathered}\text { www.sciencepubco.com/index.php/IJBR } \\ \text { doi: } 10.14419 / \text { ijbr.v2i2.2878 } \\ \text { Research Paper }\end{gathered}$

\title{
Enzymatic studies on Natural rubber biodegradation by Bacillus pumilus
}

\author{
Nayanashree.G ${ }^{1}$, Thippeswamy.B ${ }^{1 *}$, Krishnappa.M ${ }^{2}$ \\ ${ }^{1}$ Dept. of P.G. Studies and Research in Microbiology, Bio-Science Complex, Jnanasahyadri, Kuvempu University, \\ Shankaraghatta-577451, Shivamogga.(Dist.), Karnataka, INDIA \\ ${ }^{2}$ Dept. of P.G. Studies and Research in Applied Botany, Bio-Science Complex, Jnanasahyadri, Kuvempu University, \\ Shankaraghatta-577451, Shivamogga.(Dist.), Karnataka, INDIA \\ *Corresponding author E-mail: thippeswamyb205@gmail.com
}

\begin{abstract}
Objective: To isolate Natural Rubber degrading Bacteria from soil and to screen the enzymes responsible for Natural Rubber degradation.

Methods: Soil burial method was followed for isolation of bacteria. Plate assay method and liquid assay method by using Mineral Salt Medium was followed for screening of bacteria for its capacity to degrade Natural rubber. Degradation was confirmed by weight loss experiment, Scanning Electron Microscopy (SEM) and Fourier Transform Infra-Red (FTIR) studies. Enzymes responsible for Natural rubber degradation were screened and their activity was measured by spectrophotometric method.

Results: Isolated organism was identified as Bacillus pumilus. It was able to degrade Natural rubber which was confirmed by weight loss, SEM and FTIR studies. From the current work it was studied that Laccase and Manganese peroxidase were the enzymes which were responsible for Natural rubber degradation.

Conclusion: From current investigation, it can be concluded that our isolated bacterial strain Bacillus pumilus have the capacity to degrade Natural rubber and it can be useful in solving the problem caused by waste Natural rubber products in the environment.
\end{abstract}

Keywords: Bacillus Pumilus, Hevea Brasiliensis, Polyisoprene, Laccase, Manganese Peroxidase.

\section{Introduction}

Natural rubber or cahuchu is a coagulated or precipitated product obtained from latex of rubber plants (Hevea brasiliensis), which forms non linked but partially vulcanizable polymer chains having molecular masses of about $10^{6} \mathrm{Da}$ with elastic properties.

The natural rubber latex is sticky and viscous in nature and very sensitive to temperature therefore for the manufacture of rubber products this latex should be subjected to vulcanization. The global rubber consumption is estimated to be 12.5 million metric tons in 2013 of which $65 \%$ were used for tire production and other $35 \%$ is used for the production of other rubber products.

After usage of these natural rubber products, disposal of these products are the world wide solid waste problem. One of the solutions to reduce this problem is to recycle the used waste rubber. But due to the chemical cross linking formed during vulcanization it is not possible to simply melt and reshape the products as in case of polythene. So other alternatives such as microbial degradation of the product should be developed. Microbial degradation is mainly carried out by various microorganisms such as fungi and bacteria.

\section{Materials and methods}

For the isolation of bacteria which were able to degrade natural rubber, natural rubber latex and natural rubber sheet samples were collected from rubber processing unit and then it was brought to the laboratory and preserved in the refrigerator for further use.

\subsection{Isolation of Natural rubber degrading bacteria}

For the isolation of natural rubber degrading bacteria soil burial method was followed. Natural rubber small discs were weighed and initial weight was recorded. Then, these discs were dumped in the soil and left for a period of six months of time interval. These natural rubber discs were removed regularly at time interval of two, four and six months respectively and weighed. For the isolation of natural rubber degrading bacteria soil sample and natural rubber samples were plated on the nutrient agar and kept for incubation at room temperature at $37 \pm 2^{\circ} \mathrm{C}$ for 24 hours for the isolation of bacteria (Tsuchi et al., 1996).

After incubation bacteria were identified by using biochemical tests, Gram's staining, microscopic observation and by using standard manual (Peter et al., 1994). Biochemical tests used for bacterial identification were as follows, Malonate, Voges Proskauer's, Citrate, and ONPG, Nitrate reduction, Catalase, Arginine, Sucrose, Mannitol, Glucose, Arabinose and Trehalose utilization. The colonies which were isolated were preserved at $4^{\circ} \mathrm{C}$ in $2 \%$ agar slants.

2.2. Plate assay for the screening of bacteria capable of degrading Natural rubber 
For the screening of natural rubber degrading bacteria pure culture isolates were directly inoculated on the sterilized, pre weighed natural rubber discs and then kept for incubation for 2 months. Bacteria capable of degrading natural rubber utilized natural rubber as sole source of carbon and showed growth on the natura rubber discs. After a time interval of 2 months natural rubber sample inoculated with organisms were washed thoroughly, dried at $50^{\circ} \mathrm{C}$ in hot air oven for 24 hours and final weight was recorded (Borel et al.,1981).

\subsection{Screening of Natural rubber degradation by using mineral salt medium (MSM)}

Natural rubber degrading ability of the bacteria was checked in the laboratory conditions by growth experiment in mineral salt medium (MSM) (Pan et al., 2009), where natural rubber was used as sole carbon source. Previously isolated bacteria were inoculated to different conical flasks containing MSM and kept for incubation for 2 months on rotary shaker. Bacteria were incubated at $37 \pm 2^{\circ} \mathrm{C}$, triplicates were maintained. After incubation period natural rubber discs were removed and observed for the growth of bacteria Then natural rubber discs were washed dried at $50^{\circ} \mathrm{C}$ in hot air oven for 24 hours and weight loss was checked (Tsuchii and Tokiwa, 2001).

\subsection{Confirmation of Natural rubber degradation by scanning electron microscopy (SEM)}

Evidence for degradation and mineralization of cis-1, 4 polyisoprene natural rubber hydrocarbon chain was obtained by observing the natural rubber discs under SEM. For the observation natural rubber discs buried in the soil and present in the MSM, which were subjected for degradation were observed under field emission-scanning electron microscopy (FEI-SIRION, Eindhoven, Netherland) (Lions et al., 2000).

\subsection{Confirmation of Natural rubber degradation by Fourier transforms infrared spectroscopy (FTIR)}

Chemical changes that arose directly on the natural rubber surface as result of the degradation process were determined using FTIR spectroscopy. NICOLET 380 FTIR spectrophotometer from Thermo Fisher Scientific, France was used which gives transmittance spectra in IR range 4000 to $400 \mathrm{~nm}$. (Roy et al., 2005).

\subsection{Characterization of enzymes responsible for bio- degradation of Natural rubber}

It was studied that laccase and manganese peroxidase enzymes were responsible for the natural rubber degradation.

\subsection{Screening for Laccase and Manganese peroxidase enzyme production by Bacillus pumilus}

Screening for laccase enzyme produced by Bacillus pumilus was done on plates containing following composition (g/l): 3.0 peptone, 10.0 glucose, $0.6 \mathrm{KH}_{2} \mathrm{PO}_{4}, 0.001 \mathrm{ZnSO}_{4}, 0.4 \mathrm{~K}_{2} \mathrm{HPO}_{4}$ $0.0005 \mathrm{FeSO}_{4}, 0.05 \mathrm{MnSO}_{4}, 0.5 \mathrm{MgSO}_{4}, 20.0$ Agar (pH-6) supplemented with $0.02 \%$ guaiacol. Bacillus pumilus was inoculated into this plate and the plate was incubated at $30^{\circ} \mathrm{C}$ for 7 days Laccase activity was visualized on plates containing $0.02 \%$ guaiacol, since laccase catalyzes the oxidative polymerization of guaiacol to form reddish brown zones in the medium (Viswanath et. al, 2008)

For the screening of manganese peroxidase enzyme producing organisms $\mathrm{H}_{2} \mathrm{O}_{2}$ was added to the laccase screening media.

\subsection{Mass production of enzyme by submerged fermen-} tation
A pure culture of Bacillus pumilus was inoculated to submerged state fermentation medium for the production of extracellular enzymes by using MSM media and was maintained at the incubation temperature of $37 \pm 2^{\circ} \mathrm{C}$ for 2 months (Shraddha et al., 2011).

2.9. Determination of Laccase and Manganese peroxidase enzyme activity by using spectrophotometer

Guaiacol $(2 \mathrm{mM})$ in sodium acetate buffer $(10 \mathrm{mM}$ pH 5.0$)$ was used as substrate. The reaction mixture contained $3 \mathrm{ml} 10 \mathrm{mM}$ acetate buffer of $\mathrm{pH} 5,1 \mathrm{ml}$ guaiacol and $1 \mathrm{ml}$ enzyme source and enzyme blank contained $1 \mathrm{ml}$ of distilled water instead of enzyme source. The mixture was incubated at $30^{\circ} \mathrm{C}$ for 15 minutes and absorbance was read at $450 \mathrm{~nm}$ blank using UV spectrophotometer (Papinutti et al., 2006). Manganese peroxidase enzyme activity was calculated by following laccase enzyme activity determination procedure, but for the reaction mixture $1 \mathrm{ml}$ of $\mathrm{H}_{2} \mathrm{O}_{2}$ was added and incubated.

\subsection{Protein estimation}

Protein concentration was estimated to determine specific activity of enzyme. The protein concentration was determined by the Lowry's method, as described by Lowry's (1951) using Bovine Serum Albumin (BSA) as a standard, absorbance was read at $660 \mathrm{~nm}$ using JENWAY- 6305 UV-VIS Spectrophotometer.

\section{Results}

\subsection{Isolation of Natural rubber degrading bacteria}

Rubber samples and the soil sample of 2, 4 and 6 months were plated on the Nutrient agar medium, different bacteria belonging to Pseudomonas sp. and Bacillus sp. were isolated and recorded. In the isolated organism Bacillus pumilus was pre-dominant and commonly isolated. Thus it was screened to test natural rubber degrading ability. Weight loss was also observed in all the rubber samples which were removed at different time interval (Table 1).

\begin{tabular}{llllll}
\multicolumn{6}{c}{ Table1: Weight Loss of Rubber by Soil Burial Method } \\
\hline S1.No. & $\begin{array}{l}\text { Number of } \\
\text { months }\end{array}$ & $\begin{array}{l}\text { Initial } \\
\text { weight }(\mathrm{g})\end{array}$ & $\begin{array}{l}\text { Final } \\
\text { Weight }(\mathrm{g})\end{array}$ & $\begin{array}{l}\text { Weight loss } \\
(\mathrm{g})\end{array}$ & $\begin{array}{l}\text { Weight loss } \\
\text { In }(\%)\end{array}$ \\
\hline 1. & 2 & 3 & 2.84 & $0.16 \pm 0.01$ & 5.3 \\
2. & 4 & 3 & 2.63 & $0.37 \pm 0.04$ & 12.3 \\
3. & 6 & 3 & 2.12 & $0.88 \pm 0.01$ & 29.3 \\
\hline
\end{tabular}

3.2. Plate assay for the screening of bacteria capable of degrading Natural rubber

In Bacillus pumilus inoculated natural rubber discs initial weight of the rubber disc was $10 \mathrm{~g}$ and final weight was $8.98 \mathrm{~g}$ and there was decrease in $1.02 \pm 0.02 \mathrm{~g}$ weight and the percentage of weight loss was $10.2 \%$.

\subsection{Screening of Natural rubber degradation by using mineral salt medium (MSM)}

Growth experiment was conducted by using mineral salt medium weight loss was observed and growth of bacteria was observed on the natural rubber discs. Initial weight of Bacillus pumilus, inoculated sample was $3 \mathrm{~g}$ and final weight was $2.28 \mathrm{~g}$ and there was a weight loss of $0.72 \pm 0.01 \mathrm{~g}$ and there was a $24 \%$ weight loss.

\subsection{Confirmation of Natural rubber degradation by staining with Schiff's reagent}

Natural rubber discs which were inoculated with Bacillus pumilus turned to purple colour and there was no colour formation in the untreated control. Formation of purple colour in the treated sample was due to the presence of aldehyde and ketone group, which 
was produced as a result of degradation of cis-1, 4-polyisoprene units of natural rubber.

\subsection{Confirmation of Natural rubber degradation by scanning electron microscopy (SEM)}

Natural rubber discs were observed under SEM, bio-film formation, complete disintegration and formation of cavities on the natural rubber discs was observed (Fig-1).

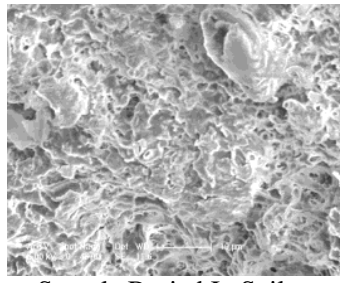

Sample Buried In Soil

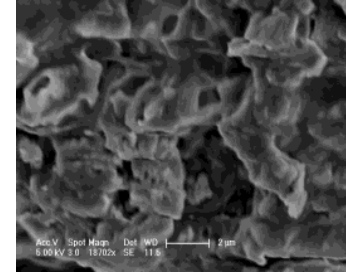

Bacillus Pumilus Treated

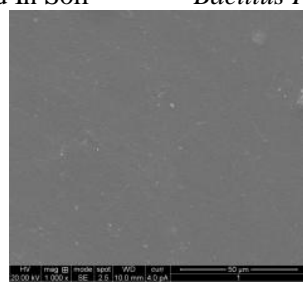

Control

Fig. 1: SEM Images of Natural Rubber Showing Degradation

\subsection{Confirmation of rubber degradation by Fourier transforms infrared spectroscopy (FTIR)}

Natural rubber discs, which was treated by Bacillus pumilus was subjected to FTIR, peaks at the wave $2723.29 \mathrm{~cm}^{-1}$ and $1660.27 \mathrm{~cm}^{-}$ ${ }^{1}$ was found, which indicates the release of aldehyde and ketone group as a result of degradation. Presence of aromatics (3024.66 cm-1), carboxylic acid $\left(2504.11 \mathrm{~cm}^{-1}\right)$, carbonyl $\left(1791.78 \mathrm{~cm}^{-1}\right)$ and alcohol $\left(1079.45 \mathrm{~cm}^{-1}\right)$ groups were observed, which confirms rubber degradation (Fig. 2).

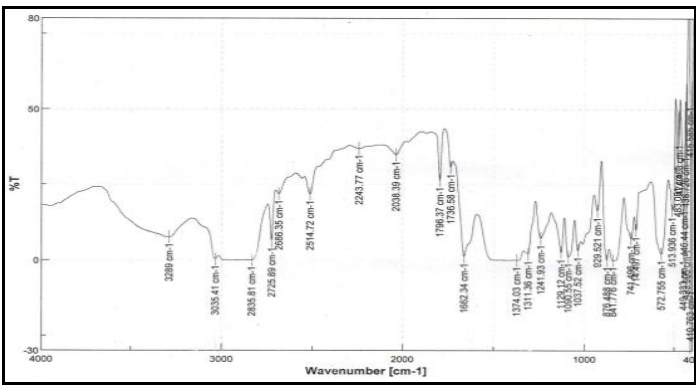

Bacillus Pumilus Treated Sample

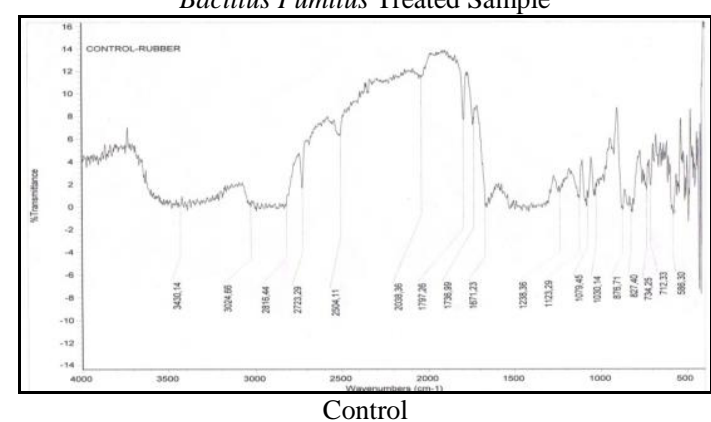

Fig. 2: Confirmation of Natural Rubber Degradation by FTIR

\subsection{Enzymatic studies of Natural rubber degradation}

It was studied that Laccase and manganese peroxidase enzymes were responsible for the rubber degradation.

\subsection{Screening for Laccase and Manganese peroxidase enzyme production by Bacillus pumilus}

Bacillus pumilus was inoculated on the laccase and manganese peroxidase medium, there was a formation of reddish brown colour around the colonies, as laccase and manganese peroxidase catalyzes the oxidative polymerization of guaiacol to form reddish brown zone. Bacillus pumilus which showed positive result for rubber degradation showed positive result for laccase and manganese peroxidase enzyme screening.

3.9. Spectrophotometric al analysis of Laccase and Manganese peroxidase enzyme activity

Bacillus pumilus showed more manganese peroxidase activity compared to laccase activity. Maximum activity of both laccase and manganese peroxidase enzyme activity was maximum in $8^{\text {th }}$ week. Laccase enzyme activity in $8^{\text {th }}$ week was $0.0105 \mathrm{IU}$ and manganese peroxidase activity in $8^{\text {th }}$ week was $0.0124 \mathrm{IU}$.

Table 2: Laccase and Manganese Peroxidase Enzyme Activity in IU

\begin{tabular}{|c|c|c|c|c|c|c|c|c|}
\hline $\begin{array}{l}\text { Ba- } \\
\text { cillu } \\
\text { s } \\
\text { pumi } \\
\text { lus }\end{array}$ & $\begin{array}{l}1^{\text {st }} \\
\mathrm{w} \\
\mathrm{ee} \\
\mathrm{k}\end{array}$ & $\begin{array}{l}2^{\text {nd }} \\
\text { week }\end{array}$ & $\begin{array}{l}3^{\text {rd }} \\
\text { week }\end{array}$ & $\begin{array}{l}4^{\text {th }} \\
\text { week }\end{array}$ & $\begin{array}{l}5^{\text {th }} \\
\text { week }\end{array}$ & $\begin{array}{l}6^{\text {th }} \\
\text { week }\end{array}$ & $\begin{array}{l}7^{\text {th }} \\
\text { week }\end{array}$ & $\begin{array}{l}8^{\text {th }} \\
\text { week }\end{array}$ \\
\hline $\begin{array}{l}\text { Lacc } \\
\text { ase }\end{array}$ & 0 & $\begin{array}{l}0.001 \\
3 \pm 0.0 \\
003\end{array}$ & $\begin{array}{l}0.001 \\
9 \pm 0.0 \\
003\end{array}$ & $\begin{array}{l}0.003 \\
2 \pm 0.0 \\
003\end{array}$ & $\begin{array}{l}0.004 \\
5 \pm 0.0 \\
003\end{array}$ & $\begin{array}{l}0.006 \\
7 \pm 0.0 \\
003\end{array}$ & $\begin{array}{l}0.007 \\
8 \pm 0.0 \\
001\end{array}$ & $\begin{array}{l}0.010 \\
5 \pm 0.0 \\
001\end{array}$ \\
\hline $\begin{array}{l}\text { Man } \\
\text { gane } \\
\text { se } \\
\text { pe- } \\
\text { roxi } \\
\text { dase }\end{array}$ & 0 & $\begin{array}{l}0.001 \\
5 \pm 0.0 \\
004\end{array}$ & $\begin{array}{l}0.002 \\
8 \pm 0.0 \\
004\end{array}$ & $\begin{array}{l}0.003 \\
8 \\
\pm 0.00 \\
01\end{array}$ & $\begin{array}{l}0.005 \\
5 \pm 0.0 \\
001\end{array}$ & $\begin{array}{l}0.007 \\
2 \pm 0.0 \\
002\end{array}$ & $\begin{array}{l}0.009 \\
3 \pm 0.0 \\
001\end{array}$ & $\begin{array}{l}0.012 \\
4 \pm 0.0 \\
004\end{array}$ \\
\hline
\end{tabular}

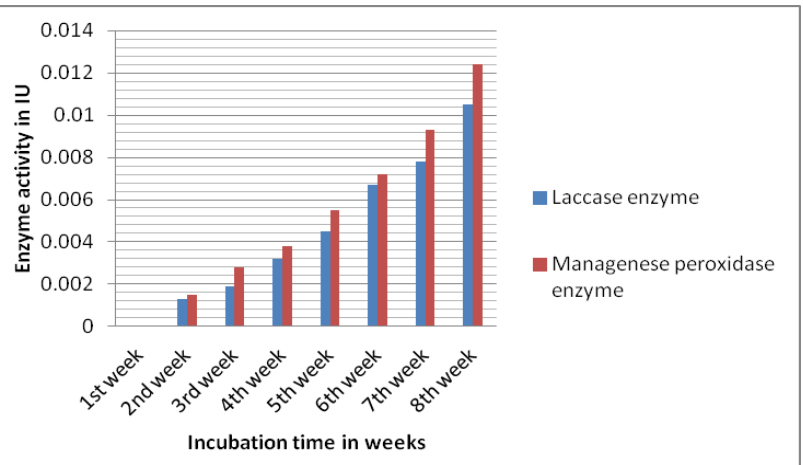

Fig. 4: Laccase and Manganese Peroxidase Enzyme Activity in IU

\subsection{Protein estimation}

Specific activity of laccase enzyme in Bacillus pumilus was $0.086 \pm 0.001 \mu \mathrm{mol} / \mathrm{ml} / \mathrm{min} / \mathrm{mg}$ and specific activity of manganese peroxidase enzyme in Bacillus pumilus was $0.101 \pm 0.1$ $\mu \mathrm{mol} / \mathrm{ml} / \mathrm{min} / \mathrm{mg}$.

\section{Discussion}

Present study was carried out to isolate natural rubber degrading fungi. It was studied that Bacillus pumilus is capable of degrading natural rubber. Degradation of natural rubber was studied by carrying out growth experiment in MSM, and degradation was confirmed by staining, SEM, FTIR and NMR studies. Further enzyme responsible for degradation was studied. Laccase and manganese peroxidase were the enzymes responsible for degradation.

Similar attempts were made by several other scientists to degrade rubber by using microorganisms.

Roy et al. (2005) made an attempt to study on natural rubber (NR) biodegradation through solid-state fermentation (SSF) and submerged fermentation (SMF) has been carried out for both bacterial as well as fungal species. There was a change in the organic car- 
bon content along with the average molecular weight of the treated rubber samples indicated rubber hydrocarbon utilization and its degradation.

Berekaa et al., (2000) conducted similar work and tested the biodegrading ability of different bacteria belonging to the genera Gordonia (strains $\mathrm{Kb} 2, \mathrm{Kd} 2$ and $\mathrm{VH} 2$ ), Mycobacterium, Micromonospora and Pseudomonas sp. All strains were able to use natural rubber (NR) as well as NR latex gloves as sole carbon source.

Similar study was carried out by Tokiwa et al. (1999) in his study he showed that forty-seven percent of a tire tread strip with a natural rubber content of $100 \mathrm{phr}$ (parts per hundred of rubber) was completely mineralized by a mutant strain, Rc, of the rubberdegrading organism, Nocardia sp. Strain 835A.

\section{Conclusion}

Rubber products are widely used in our daily life. These products are made up of natural vulcanized rubber and other chemical additives. Due to vulcanization of the natural rubber these rubber are very resistant to high temperature and persist in environment for very long time. Rubber materials have been increasingly used now days in different area after usage its disposal is a very big solid waste problem. It cannot be easily recycled due to the sulphur cross linking formed during vulcanization. If they are burnt they release enormous amount of carbon-di-oxide and some other gases which cause environmental pollution and contribute to the global warming. Rubber products such as balloon which are disposed in the natural environment are considered to be dangerous to wild animals if they are consumed by animals.

So one of the alternative ways to solve these problems is to subject these products to biodegradation. During the present study rubber discs which were dumped in the soil were removed at regular interval of time and then plated on the media to isolate the organism. In the isolated organism and Bacillus pumilus effectively degraded the rubber sample. The present study has showed that, it is possible to use Bacillus pumilus to degrade natural rubber effectively. Along with these enzymes responsible for natural rubber degradation was also characterized.

\section{References}

[1] Berekaa, M.M., Lions, A., Reichelt, R., Keller, U. and Steinbuchel, A. 2000. Effect of pretreatment of rubber material on its Biodegradability by various rubber degrading Bacteria, FEMS Microbiology Letters, 184: 199-206.

[2] Borel, M., Kergomard, A., and Renard, F. 1981. Degradation of Natural rubber by Bacteria imperfecti, Agricultural Biology and Chemistry, 46: $877-881$.

[3] Lions, A., Rudolf Reichelt, R., Keller, U. and Steinbuchel, A. 2000. A Gram negative bacterium identified as Pseudomonas aeruginosa AL98, is a potent degrader of natural rubber and synthetic cis-1,4polyisoprene, FEMS Microbiology Letters, 182: 155-161.

[4] Lowry, O.H., Rosebrough, N.J., Farr, A.L., and Randall, R.J., 1951. Protein measurement with the folin phenol reagent, Journal of general Microbiology, 31:3017-3027.

[5] Pan, L., Gung, G.J., Yin, B. and Cheng, P.S. 2009. Contribution to deterioration of polymeric materials by slow growing Bacteria Nocardia corynebacterioides, International Biodegradation and Biodeterioration, 63: 24-29.

[6] Papinutti, L., and Martinez, J. M., 2006. Production and Characterization of Laccase and Manganese peroxidase from the ligninolytic fungus Fomes sclerodermeus, Journal of technology and biotechnology, 81:1064-1070.

[7] Peter, H.A., James, T. and Stanley, T. 1994. Bergey's manual of determinative bacteriology. $9^{\text {th }}$ edition: $1-754$.

[8] Roy, V.R., Das, M., Banrjee, R. and Bhowmick, A. 2005. Comparative studies on rubber biodegradation through Solid state and submerged fermentation, Process Biochemistry, 42: 181-186.

[9] Shraddha, Shekher, R., Sehgal, S., Kamtania, M., and Kumar, A., 2011. Laccase microbial source Production, Purification, Potential biotechnological application, Enzyme Research, 1-11.
[10]Shah, A.A., Hasan, F., Hameed, A and Ahmed, S. 2008. Biological degradation of Plastics: A comprehensive review. Biotechnology Advances, 26:246 265 .

[11]Viswanath, B., Chandra, M. S., Pallavi, H., Reddy, 2008. Screening and Assessment of Laccase Producing Bacteria isolated from different environmental samples, African Journal of Biotechnology, 7:11291133

[12]Tsuchii, A. and Tokiwa, Y. 1999. Colonization and disinteragration of Tire Rubber by a colonial Mutant of Nocardia, Journal of Bioscience and Bioengineering, 87: 542-544.

[13]Tsuchii, A. and Tokiwa, Y. 2001. Microbial degradation of Tire rubber particles, Biotechnology Letters, 23: 963-969.

[14]Tsuchii, A., Takeda, K., Suzuki, T. and Tokiwa, Y. 1996. Colonization and degradation of rubber pieces by Nocardia species, Biodegradation Journal, 7: 41-48. 